\title{
A palladium single-atom catalyst toward efficient activation of molecular oxygen for cinnamyl alcohol oxidation
}

\author{
Qinghao Shang a,b, Nanfang Tang a,\#, Haifeng Qi a ab, Shuai Chen a, Guoliang Xua ${ }^{\text {a }}$, Chuntian $\mathrm{Wu}^{\mathrm{a}}$, \\ Xiaoli Pan a, Xiaodong Wang a, Yu Cong a,* \\ a CAS Key Laboratory of Science and Technology on Applied Catalysis, Dalian Institute of Chemical Physics, Chinese Academy of Sciences, Dalian 116023, \\ Liaoning, China \\ b University of Chinese Academy of Sciences, Beijing 100049, China
}

\section{A R T I C L E I N F O}

\section{Article history:}

Received 27 February 2020

Accepted 31 March 2020

Published 5 December 2020

\section{Keywords:}

Single-atom catalysis

Palladium

Alcohol oxidation

Oxygen activation

Metal support interaction

\begin{abstract}
A B S T R A C T
Selective aerobic oxidation of alcohols under mild conditions is of great importance yet challenging, with the activation of molecular oxygen $\left(\mathrm{O}_{2}\right)$ as a crucial capability of the catalysts. Herein, we demonstrate that an $\mathrm{Al}_{2} \mathrm{O}_{3}$-supported $\mathrm{Pd}$ single-atom catalyst leads to higher activity and selectivity compared to Pd nanoparticles for the oxidation of cinnamyl alcohol. The $\mathrm{Al}_{2} \mathrm{O}_{3}$ support used in this study is rich in coordinately unsaturated $\mathrm{Al}^{3+}$ sites, which are apt for binding to Pd atoms through oxygen bridges and present a distinct metal-support interaction (MSI). The suitable MSI then leads to a unique electronic characteristic of the Pd single atoms, which can be confirmed via X-ray photoelectron spectroscopy, normalized X-ray absorption near-edge structure, and diffuse reflectance Fourier transform infrared spectroscopy. Moreover, this unique electronic state is proposed to be responsible for its high catalytic activity. With the help of in-situ UV-vis spectra and electron spin resonance spectra, a specific alcohol oxidation route with $\mathrm{O}_{2}$ activation mechanism is then identified. Active oxygen species behaving chemically like singlet- $\mathrm{O}_{2}$ are generated from the interaction of $\mathrm{O}_{2}$ with $\mathrm{Pd}_{1} / \mathrm{Al}_{2} \mathrm{O}_{3}$, and then oxidize the partially dehydrogenated intermediates produced by the adsorbed allylic alcohols and Pd atoms to the desired alkenyl aldehyde. This work provides a promising path for the design and development of high-activity catalysts for aerobic oxidation reactions.
\end{abstract}

(C) 2020, Dalian Institute of Chemical Physics, Chinese Academy of Sciences. Published by Elsevier B.V. All rights reserved.
Selective aerobic oxidation of organic molecules (including alcohols, glucoses, hydrocarbons, and $\mathrm{CO}$ ) under mild conditions is a great fundamental and practical issue in modern chemistry [1-3]. Because the ground state of molecular oxygen $\left(\mathrm{O}_{2}\right)$ is a triplet state, reactions between organic molecules (mainly in a singlet state) and ground-state $\mathrm{O}_{2}$ to produce new singlet compounds are generally forbidden by the Wigners spin selection rules $[4,5]$. Therefore, efficiently activating $\mathrm{O}_{2}$ under mild reaction conditions is considered as a critical step and the greatest challenge.

In principle, organometallic catalysts, like metal alkoxides, show significant advantages in the oxidation of alcohols, owing to their defined coordination geometry, uniform active metal center, and ligands. However, their application is largely limited by their poor separation and recovery performance [6]. Since Zhang et al. [7] reported a Pt single-atom catalyst (SAC)

\footnotetext{
* Corresponding author. Tel: +86-411-84379676; Fax: +86-411-84685940; E-mail: ycong@dicp.ac.cn

\# Corresponding author. E-mail: nftang@dicp.ac.cn

This work was supported by National Natural Science Foundation of China (21802134) and National Science and Technology Major Project of China (2017-III-0005-0030).

DOI: 10.1016/S1872-2067(20)63651-8 | http://www.sciencedirect.com/science/journal/18722067 | Chin. J. Catal., Vol. 41, No. 12, December 2020
} 
exhibiting extremely high activity for CO oxidation and proposed the concept of SACs in 2011, atomically dispersed catalysts have attracted enormous attention in the catalysis field [7-11]. Because individual metal atoms in SACs are usually stabilized by covalent coordination or ionic interactions with neighboring surface atoms like homogeneous catalysts, single-atom catalysis has been regarded as a bridge to connect homogeneous and heterogeneous catalysis [12-14]. For these reasons, currently, it has become highly desirable to develop heterogeneous SACs with reactivity and atom efficiency equivalent to those of homogeneous catalysts.

An increasing number of researchers have been studying SACs in oxidation reactions with $\mathrm{O}_{2}$ as the oxidant. Li et al. [15] reported that ceria-supported $\mathrm{Au}$ and Pt SACs showed high activity and selectivity for benzyl alcohol oxidation owing to the restricted geometries of the active sites, which was because the lattice oxygen activated at the interfacial sites exhibited higher selectivity than the $\mathrm{O}_{2}$ activated on the metal surfaces. Hackett et al. [16] reported that atomically dispersed Pd demonstrated exceptional conversion in the aerobic selective oxidation (SELOX) of allylic alcohols, and the highest activity or the maximum turnover frequency (TOF) value could be achieved on the Pd SACs according to their correlation of activity with Pd size. Although some promising results have been obtained on atomically dispersed catalysts, the activation mechanism of $\mathrm{O}_{2}$ and the reaction route of SELOX of allylic alcohols are still ambiguous.

In this work, atomic and nano-dispersed Pd catalysts (labeled as $\mathrm{Pd}_{1} / \mathrm{Al}_{2} \mathrm{O}_{3}$ and $\mathrm{Pd} / \mathrm{Al}_{2} \mathrm{O}_{3}$ ) were facilely prepared with the same loading amount (0.5 wt\%) of Pd anchored onto an $\mathrm{Al}_{2} \mathrm{O}_{3}$ support rich in penta-coordinate $\mathrm{Al}^{3+}\left(\mathrm{Al}^{3+}{ }_{\text {penta) }}\right.$ centers. The $\mathrm{Pd}_{1} / \mathrm{Al}_{2} \mathrm{O}_{3}$ catalyst displayed extremely high activity for the aerobic oxidation of cinnamyl alcohol with a conversion of $92 \%$ at $80^{\circ} \mathrm{C}$ after an 8 -h reaction. Its TOF was 15.5 fold of that over nano $\mathrm{Pd} / \mathrm{Al}_{2} \mathrm{O}_{3}$ and superior or comparable to other reported catalysts with similar metal loading under the same reaction
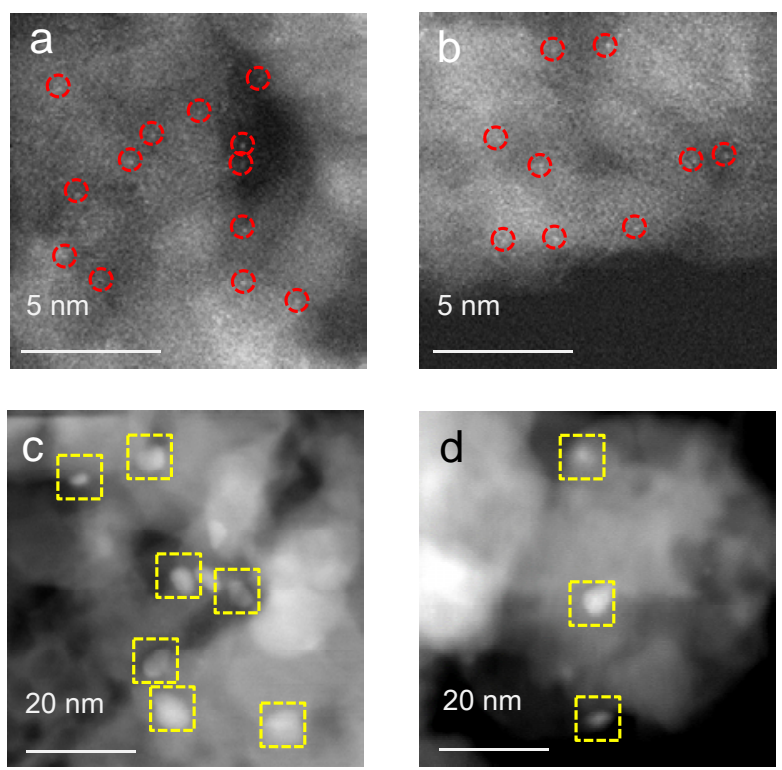

Fig. 1. HAADF-STEM images of $\mathrm{Pd}_{1} / \mathrm{Al}_{2} \mathrm{O}_{3}(\mathrm{a}, \mathrm{b})$ and $\mathrm{Pd} / \mathrm{Al}_{2} \mathrm{O}_{3}(\mathrm{c}, \mathrm{d})$. conditions. The specific $\mathrm{O}_{2}$ activation mechanism and the alcohol oxidation route were also proposed.

The morphologies of the two catalysts were determined with aberration-corrected high-angle annular dark-field scanning transmission electron microscopy (HAADF-STEM) and extended X-ray absorption fine structure (EXAFS) spectrometry. In the HAADF-STEM images in Figs. 1 (a) and (b), $\mathrm{Pd}_{1} / \mathrm{Al}_{2} \mathrm{O}_{3}$ clearly displays bright dots of single atoms marked with red circles. No nano Pd particles were observed in Fig. S1, and its X-ray diffraction (XRD) pattern in Fig. S2 only showed typical peaks of $\mathrm{Al}_{2} \mathrm{O}_{3}$ (JCPDS No. 10-0425). By comparison, $\mathrm{Pd} / \mathrm{Al}_{2} \mathrm{O}_{3}$ shows nanoparticles with sizes of 3-7 nm, marked by yellow boxes in Figs. 1(c) and (d), and no Pd single atoms were observed in Fig. S3, in consistent with its XRD pattern (Fig. S2) in which a small peak of Pd (JCPDS No. 46-1043) arose. The detailed structure properties of all the samples are listed in Table S1.

In the case of EXAFS spectra, only one notable peak at $1.58 \AA$ attributed to $\mathrm{Pd}-\mathrm{O}$ coordination $[17,18]$ was detected in $\mathrm{Pd}_{1} / \mathrm{Al}_{2} \mathrm{O}_{3}$, as presented in Fig. 2, whereas no appreciable $\mathrm{Pd}-\mathrm{Pd}$ coordination peak was identified, again verifying the existence of $\mathrm{Pd}$ single atoms. For $\mathrm{Pd} / \mathrm{Al}_{2} \mathrm{O}_{3}$, only one main peak at $2.55 \AA$ was detected, which was corresponding to the coordination of $\mathrm{Pd}-\mathrm{Pd}$, whereas no peak related to $\mathrm{Pd}-\mathrm{O}$ bonds was measured. These results indicated the characteristics of the two catalysts, i.e., they are either entirely isolated Pd single atoms or completely $\mathrm{Pd}$ nanoparticles, with the same Pd loading amount on the $\mathrm{Al}_{2} \mathrm{O}_{3}$ support.

Cinnamyl alcohol was then chosen to evaluate the aerobic SELOX performance of the two catalysts. $\mathrm{Pd}_{1} / \mathrm{Al}_{2} \mathrm{O}_{3}$ demonstrated extremely high activity relative to $\mathrm{Pd} / \mathrm{Al}_{2} \mathrm{O}_{3}$. Approximately $92 \%$ conversion of cinnamyl alcohol was obtained on $\mathrm{Pd}_{1} / \mathrm{Al}_{2} \mathrm{O}_{3}$ at $80{ }^{\circ} \mathrm{C}$ under $1 \mathrm{~atm}$ after an 8-h reaction (Fig. 3(a)), together with excellent selectivity of $91 \%$ to cinnamaldehyde. In comparison on $\mathrm{Pd} / \mathrm{Al}_{2} \mathrm{O}_{3}$, only $29 \%$ conversion with $89 \%$ selectivity was achieved under the same reaction conditions. Lowering the Pd loading to $0.05 \%$ in weight, for which the atomically dispersed HAADF-STEM images are shown in Fig. S4, also obtained a higher cinnamyl alcohol conversion of $44 \%$ (Table S2), better than that of the nano $\mathrm{Pd} / \mathrm{Al}_{2} \mathrm{O}_{3}$ catalyst with

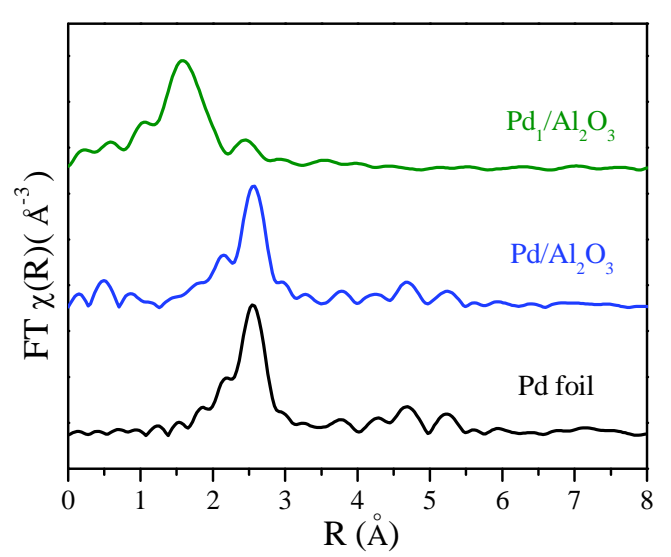

Fig. 2. FT-EXAFS spectra of $\mathrm{Pd}_{1} / \mathrm{Al}_{2} \mathrm{O}_{3}, \mathrm{Pd} / \mathrm{Al}_{2} \mathrm{O}_{3}$, and bulk palladium foil at the Pd K-edge. 

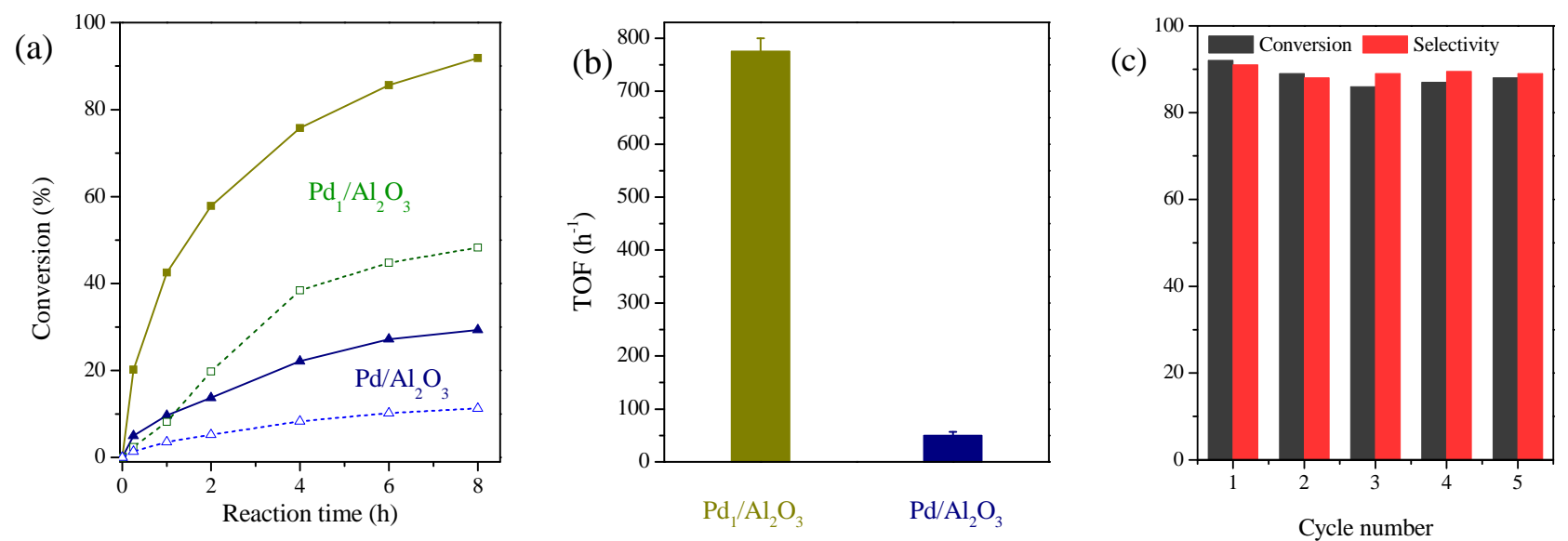

Fig. 3. (a) Conversion of alcohol oxidation with different catalysts (solid line, cinnamyl alcohol; dashed line, benzyl alcohol); (b) TOF values of different catalysts in cinnamyl alcohol oxidation; (c) Conversion and selectivity for cinnamyl alcohol oxidation over the $\mathrm{Pd}_{1} / \mathrm{Al}_{2} \mathrm{O}_{3}$ catalyst in the recycling tests. Reaction conditions: Catalyst $40 \mathrm{mg}$, alcohol $(1 \mathrm{mmol})$ in $10 \mathrm{~mL}$ toluene, $80{ }^{\circ} \mathrm{C}$, and oxidant $\mathrm{O}_{2}(1 \mathrm{~atm})$.

$0.5 \mathrm{wt} \%$ loading. For the low conversion below $30 \%$, the TOF value of $\mathrm{Pd}_{1} / \mathrm{Al}_{2} \mathrm{O}_{3}$ was calculated as $775 \mathrm{~h}^{-1}$ (Fig. 3(b)), which was 15.5 times higher than that of $\mathrm{Pd} / \mathrm{Al}_{2} \mathrm{O}_{3}\left(50 \mathrm{~h}^{-1}\right)$. This performance is superior to many other catalysts with similar metal loadings reported in the literature (Table S3). High activity in SELOX of another primary alcohol, i.e., benzyl alcohol, was also achieved on $\mathrm{Pd}_{1} / \mathrm{Al}_{2} \mathrm{O}_{3}$, as displayed in Fig. 3(a). The apparent barrier energy ( $E_{\text {app }}$ ) of $\mathrm{Pd}_{1} / \mathrm{Al}_{2} \mathrm{O}_{3}$ derived from the Arrhenius plot (Fig. S5) was fairly low (34.1 $\left.\pm 5.7 \mathrm{~kJ} \mathrm{~mol}^{-1}\right)$ compared to those of $\mathrm{Pd} / \mathrm{Al}_{2} \mathrm{O}_{3}$ and similar catalysts $[16,19]$, which reflects its high activity from another aspect. We further tested the reusability of the $\mathrm{Pd}_{1} / \mathrm{Al}_{2} \mathrm{O}_{3}$ sample and observed no significant changes in either the conversion or the selectivity over five cycles (Fig. 3(c)).

To elaborate the high catalytic performance of the $\mathrm{Pd}_{1} / \mathrm{Al}_{2} \mathrm{O}_{3}$ $\mathrm{SAC}$, the electronic states of the Pd species were examined in detail with X-ray photoelectron spectroscopy (XPS), normalized X-ray absorption near-edge structure (XANES), and diffuse reflectance Fourier transform infrared spectroscopy (CO-DRIFT). As shown in the Pd 3d XPS spectra in Fig. 4(a), the peaks at 336.7 and $336.9 \mathrm{eV}$ of the unreduced $\mathrm{Pd} / \mathrm{Al}_{2} \mathrm{O}_{3}$ and $\mathrm{Pd}_{1} / \mathrm{Al}_{2} \mathrm{O}_{3}$ could be ascribed to $\mathrm{PdO}$ [20-22]. After reduction at $400{ }^{\circ} \mathrm{C}$, the $\mathrm{Pd} 3 d_{5 / 2}$ peak of $\mathrm{Pd} / \mathrm{Al}_{2} \mathrm{O}_{3}$ shifted to a lower binding energy (BE) of $335.0 \mathrm{eV}$, which is awarded to the $\mathrm{Pd}^{0}$ species. In comparison, $\mathrm{Pd}_{1} / \mathrm{Al}_{2} \mathrm{O}_{3}$ shifted the $\mathrm{Pd} 3 d_{5 / 2}$ peak to $336.6 \mathrm{eV}$, corresponding to a partially reduced $\mathrm{Pd}^{\delta+}$ state [21]. The normalized XANES spectra shown in Fig. 4(b) could confirm the above analysis. The white-line intensity of the $\mathrm{Pd}$ species of $\mathrm{Pd}_{1} / \mathrm{Al}_{2} \mathrm{O}_{3}$ was much higher than those of $\mathrm{Pd} / \mathrm{Al}_{2} \mathrm{O}_{3}$ and $\mathrm{Pd}$ foil, indicating that the Pd species were positively charged. The CO adsorption behavior could further attest to this. As illustrated by the CO-DRIFT in Fig. 4(c), two CO stretching vibration bands were observed at 1987 and $2079 \mathrm{~cm}^{-1}$ on $\mathrm{Pd} / \mathrm{Al}_{2} \mathrm{O}_{3}$. The former is attributed to bridge-adsorbed $\mathrm{CO}$ on the step sites of the $\mathrm{Pd}^{0}$ nanoparticles, and the latter is assigned to the linear-adsorbed $\mathrm{CO}$ on the $\mathrm{Pd}^{0}$ (111) facets [23-25]. For $\mathrm{Pd}_{1} / \mathrm{Al}_{2} \mathrm{O}_{3}$, only one adsorption band at $2073 \mathrm{~cm}^{-1}$ was observed, ascribed to the $\mathrm{CO}$ adsorbed on the $\mathrm{Pd}^{\delta+}$ atoms in a top configuration [26,27]. In correlation with the catalytic performance, the partially reduced $\mathrm{Pd}$ atoms could be proposed as active sites for $\mathrm{Pd}_{1} / \mathrm{Al}_{2} \mathrm{O}_{3}$, well consistent with previous reports $[28,29]$. On the other hand, one may notice that the peak position of the linear $\mathrm{CO}$ on $\mathrm{Pd}_{1} / \mathrm{Al}_{2} \mathrm{O}_{3}$ was slightly red-shifted in comparison to that on $\mathrm{Pd} / \mathrm{Al}_{2} \mathrm{O}_{3}$. This suggested that the electrons of Pd may easily transfer from the atomically dispersed samples.

Based on the above, the $\mathrm{Pd}_{1} / \mathrm{Al}_{2} \mathrm{O}_{3} \mathrm{SAC}$ possesses a unique
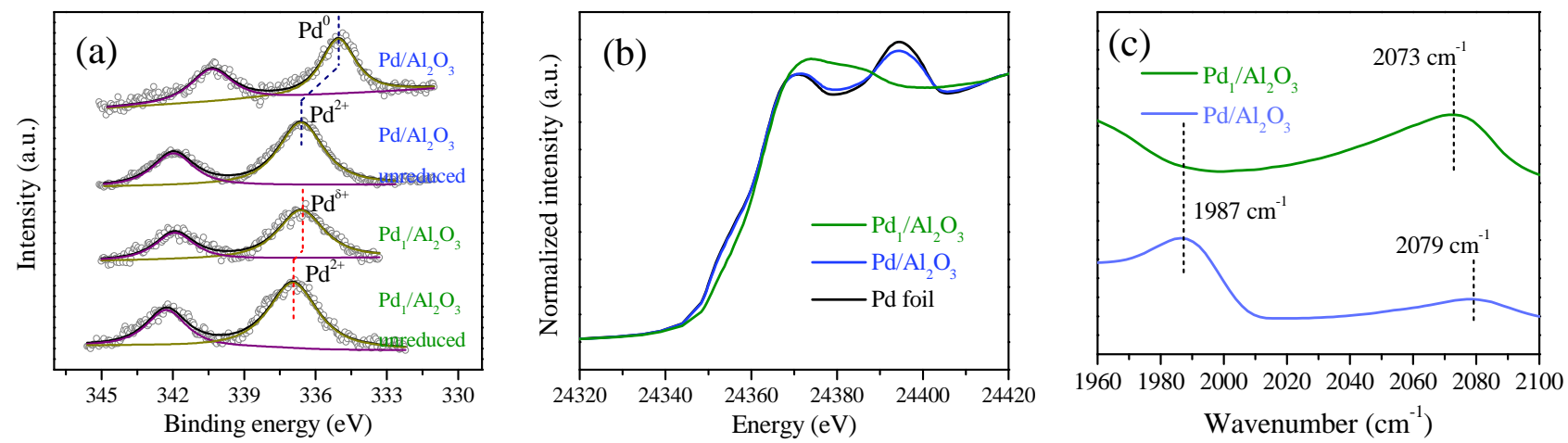

Fig. 4. (a) Pd $3 d \mathrm{XPS}$ spectra of $\mathrm{Pd}_{1} / \mathrm{Al}_{2} \mathrm{O}_{3}$ and $\mathrm{Pd} / \mathrm{Al}_{2} \mathrm{O}_{3}$ with and without reduction; (b) Normalized XANES spectra at the Pd K-edge with $\mathrm{Pd}$ foil as reference; (c) CO-DRIFT spectra of $\mathrm{Pd}_{1} / \mathrm{Al}_{2} \mathrm{O}_{3}$ and $\mathrm{Pd} / \mathrm{Al}_{2} \mathrm{O}_{3}$. 


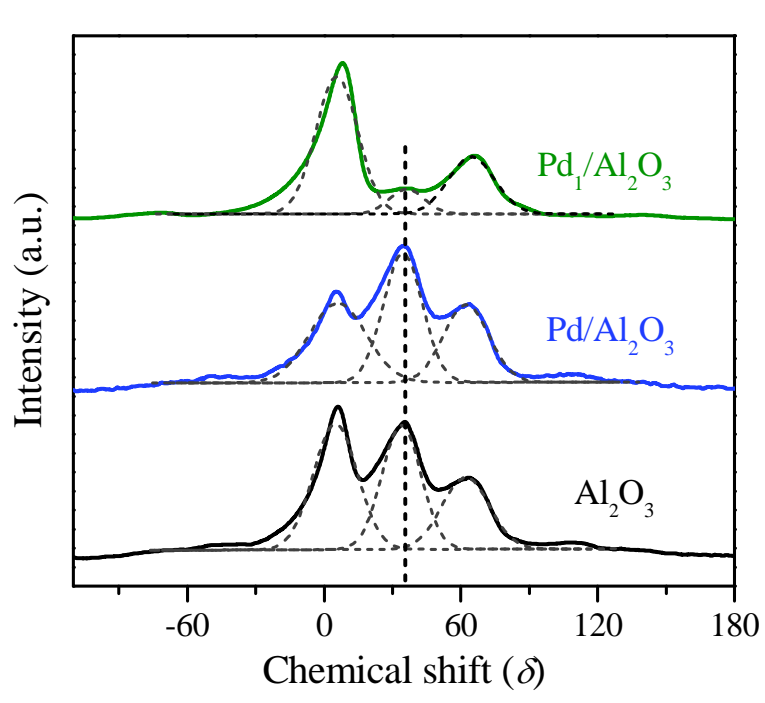

Fig. 5. ${ }^{27} \mathrm{Al}$ MAS NMR spectra (solid line) and their deconvolution results (short dot) of $\mathrm{Pd}_{1} / \mathrm{Al}_{2} \mathrm{O}_{3}, \mathrm{Pd} / \mathrm{Al}_{2} \mathrm{O}_{3}$, and $\mathrm{Al}_{2} \mathrm{O}_{3}$.

electronic state. It has been reported that the interaction between the metal and support affects the physiochemical property and catalytic performance of a catalyst severely [30-32]. Herein, the different preparation methods may result in different metal-support interactions (MSIs) between $\mathrm{Pd}$ and $\mathrm{Al}_{2} \mathrm{O}_{3}$, thereby leading to a distinct electronic state of the Pd species. To testify this, ${ }^{27} \mathrm{Al}$ magic-angle spinning (MAS) nuclear magnetic resonance (NMR) spectroscopy was employed. Three characteristic peaks centered at 5,35 , and $65(\delta)$ were observed for all the samples (Fig. 5), which are attributed to $\mathrm{Al}^{3+}$ cations in octahedral $\left(\mathrm{Al}^{3+}{ }_{\mathrm{octa}}\right)$, pentahedral $\left(\mathrm{Al}^{3+}{ }_{\text {penta }}\right)$, and tetrahedral $\left(\mathrm{Al}^{3+}{ }_{\text {tetra }}\right)$ coordination, respectively [33]. Among them, the $\mathrm{Al}^{3+}{ }_{\text {penta }}$ sites are coordinately unsaturated, apt for binding to metal atoms through oxygen bridges; thus, the intensity change of $\mathrm{Al}^{3+}$ penta could reflect the interaction between $\mathrm{Pd}$ and $\mathrm{Al}_{2} \mathrm{O}_{3}$. As shown in the spectra, $\mathrm{Pd}_{1} / \mathrm{Al}_{2} \mathrm{O}_{3}$ presented a substantial drop in the $\mathrm{Al}^{3+}$ penta intensity compared to pure $\mathrm{Al}_{2} \mathrm{O}_{3}$, indicating that strong interactions occurred between $\mathrm{Al}^{3+}$ penta and $\mathrm{Pd}$ atoms during calcination and reduction. In comparison for $\mathrm{Pd} / \mathrm{Al}_{2} \mathrm{O}_{3}$, the number of $\mathrm{Al}^{3+}{ }_{\text {penta }}$ sites remained almost un- changed under the same treatment, revealing a weak MSI. This is probably the consequence of the physical barrier of the inverse nano micelles-encapsulated Pd precursors, which are formed by surfactant P123 during the nucleation and calcination process. In addition, a strong MSI could also explain the higher $\mathrm{BE}$ of $\mathrm{Pd} 3 d_{5 / 2}$ in the unreduced $\mathrm{Pd}_{1} / \mathrm{Al}_{2} \mathrm{O}_{3}(336.9 \mathrm{eV}$ ) than that in $\mathrm{Pd} / \mathrm{Al}_{2} \mathrm{O}_{3}(336.7 \mathrm{eV})$, as the $\mathrm{PdO}$ species in $\mathrm{Pd}_{1} / \mathrm{Al}_{2} \mathrm{O}_{3}$ are mostly located on the $\mathrm{Al}^{3+}$ penta sites.

It is well known that $\mathrm{O}_{2}$ activation is extremely critical to oxidation reactions. According to the Wigners spin selection rule, high-energy oxygen species $\left(e . g ., \mathrm{O}_{2}{ }^{-}, \cdot \mathrm{OH}\right.$, and $\left.{ }^{1} \mathrm{O}_{2}\right)$ activated from ground-state $\mathrm{O}_{2}$ are highly desirable for the oxidation reaction. To decode the detailed activation process and reaction mechanism, in-situ UV-vis spectra were collected in this study. As presented in Fig. 6(a), the cinnamyl alcohol showed an absorption peak at $281.8 \mathrm{~nm}$ and a shoulder peak at $293.0 \mathrm{~nm}$ with or without $\mathrm{Pd} / \mathrm{Al}_{2} \mathrm{O}_{3}$, assigned to the $\pi-\pi^{*}$ transition of the conjugated bonds between the benzene ring and $\mathrm{C}=\mathrm{C}$. Contrastingly, a remarkable red shift from 281.8 to 284.2 nm occurred on contact with $\mathrm{Pd}_{1} / \mathrm{Al}_{2} \mathrm{O}_{3}$, owing to the effective expansion of the $\pi$-conjugation induced by the charge or energy transfer between the adsorbed cinnamyl alcohol and $\mathrm{Pd}$ single atoms on $\mathrm{Pd}_{1} / \mathrm{Al}_{2} \mathrm{O}_{3}$ [34]. This indicates that cinnamyl alcohol molecules adsorb over the single-atom $\mathrm{Pd}$ sites and form partially dehydrogenated intermediates. To detect the activated state of $\mathrm{O}_{2}, 2,2,6,6$-tetramethyl-4-piperidone (4-oxo-TMP) was used as a probe molecule for electron spin resonance (ESR) examination in view of its preferable ability to trap singlet oxygen species $\left({ }^{1} \mathrm{O}_{2}\right)$ [35]. As shown in Fig. 6(b), no ESR signals were perceived for the $\mathrm{Al}_{2} \mathrm{O}_{3}$ support, whereas triplet ESR signals were observed for $\mathrm{Pd}_{1} / \mathrm{Al}_{2} \mathrm{O}_{3}$ and $\mathrm{Pd} / \mathrm{Al}_{2} \mathrm{O}_{3}$, suggesting that an active oxygen species behaving chemically like singlet- $\mathrm{O}_{2}$ was formed during the $\mathrm{O}_{2}$ activation process. Compared to $\mathrm{Pd} / \mathrm{Al}_{2} \mathrm{O}_{3}, \mathrm{Pd}_{1} / \mathrm{Al}_{2} \mathrm{O}_{3}$ showed an enhanced signal of the singlet $\mathrm{O}_{2}$ species, presenting a stronger ability for $\mathrm{O}_{2}$ activation. In addition, 5, 5-dimethyl-1-pyrroline $\mathrm{N}$-oxide (DMPO) was employed as a probing molecule to further identify other oxygen species. No DMPO/•OH (1:2:2:1 quartet signal) or DMPO $/ \bullet^{-} \mathrm{O}_{2}^{-}(1: 1: 1: 1: 1: 1$ 6-line signal) signal was detected $[4,36]$, suggesting that no superoxide $\left(\mathrm{O}_{2}^{-}\right)$and hydroxyl radicals $(\cdot \mathrm{OH})$ species are produced in these systems (Fig. S6).
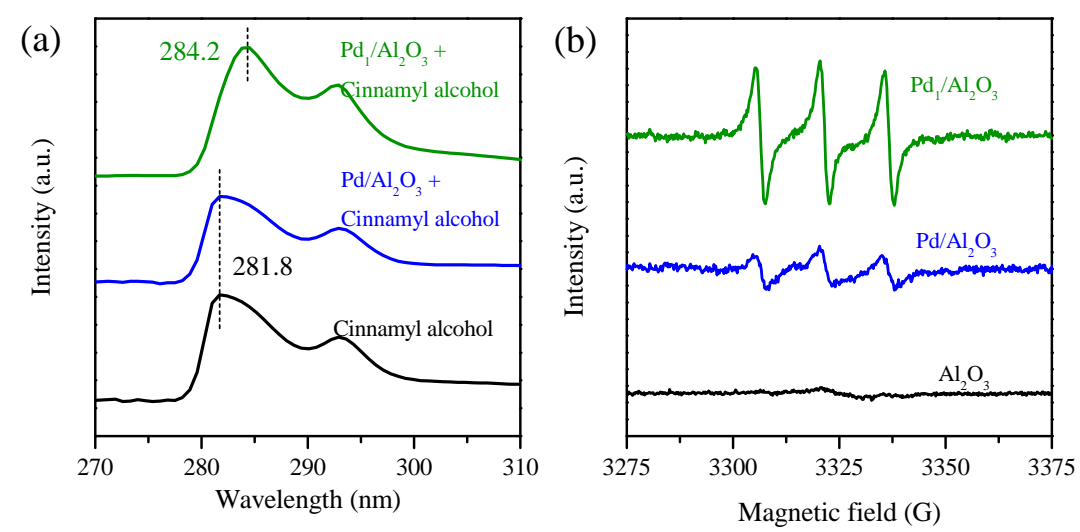

Fig. 6. (a) UV-vis spectra of cinnamyl alcohol in toluene with and without the catalysts; (b) ESR spectra of samples formed by mixing a solution of 4-oxo-TMP with the catalysts at $60^{\circ} \mathrm{C}$. 
Based on the above results, a stepwise reaction process was proposed for aerobic SELOX of allylic alcohols over the $\mathrm{Pd}_{1} / \mathrm{Al}_{2} \mathrm{O}_{3}$ catalyst. First, partial dehydrogenation occurs through a charge transfer between the adsorbed allylic alcohols and the Pd atoms. Concurrently, active oxygen species behaving chemically like singlet- $\mathrm{O}_{2}$ are generated on the interaction of $\mathrm{O}_{2}$ with $\mathrm{Pd}_{1} / \mathrm{Al}_{2} \mathrm{O}_{3}$. Then, the active oxygen species oxidize the partially dehydrogenated intermediates to the desired alkenyl aldehyde.

In summary, atomic and nano-dispersed catalysts are prepared with the same $\mathrm{Pd}$ loading on an $\mathrm{Al}_{2} \mathrm{O}_{3}$ support. Because of the different strengths of the MSI, the single-atom $\mathrm{Pd}_{1} / \mathrm{Al}_{2} \mathrm{O}_{3}$ catalyst exhibits much higher catalytic activity than the nano $\mathrm{Pd} / \mathrm{Al}_{2} \mathrm{O}_{3}$ catalyst for the aerobic SELOX of allylic alcohols under mild conditions. The partially positive electronic properties of the single-atom Pd sites are expected to lead to the more efficient activation of allylic alcohols and $\mathrm{O}_{2}$. This work offers a promising path for the design and development of highly active catalysts for aerobic oxidation reactions.

\section{Acknowledgments}

We are grateful to the BL $14 \mathrm{~W}$ beamline at the Shanghai Synchrotron Radiation Facility (SSRF).

\section{References}

[1] R. A. Sheldon, J. K. Kochi, Metal-Catalyzed Oxidation of Organic Compounds, Academic Press, 1981.

[2] F. Su, Y. Liu, L. Wang, Y. Cao, H. He, K. Fan, Angew. Chem. Int. Ed., 2008, 47, 334-337.

[3] S. S. Stahl, Angew. Chem. Int. Ed., 2004, 43, 3400-3420.

[4] R. Long, H. Huang, Y. Li, L. Song, Y. Xiong, Adv. Mater., 2015, 27, 7025-7042.

[5] D. Kovalev, M. Fujii, Adv. Mater., 2005, 17, 2531-2544.

[6] R. A. Sheldon, I. W. C. E. Arends, G. J. Ten Brink, A. Dijksman, Acc. Chem. Res., 2002, 35, 774-781.

[7] B. T. Qiao, A. Q. Wang, X. F. Yang, L. F. Allard, Z. Jiang, Y. T. Cui, J. Y.
Liu, J. Li, T. Zhang, Nat. Chem., 2011, 3, 634-641.

[8] P. X. Liu, Y. Zhao, R. X. Qin, S. G. Mo, G. X. Chen, L. Gu, D. M. Chevrier, P. Zhang, Q. Guo, D. D. Zang, B. H. Wu, G. Fu, N. F. Zheng, Science, 2016, 352, 797-801.

[9] L. Nie, D. Mei, H. Xiong, B. Peng, Z. Ken, X. I. P. Hernandez, A. DeLariva, M. Wang, M. H. Engelhard, L. Kovarik, A. K. Datye, Y. Wang, Science, 2017, 358, 1419-1423.

[10] P. Y. Xin, J. Li, Y. Xiong, X. Wu, J. C. Dong, W. X. Chen, Y. Wang, L. Gu, J. Luo, H. P. Rong, C. Chen, Q. Peng, D. S. Wang, Y. D. Li, Angew. Chem. Int. Ed., 2018, 57, 4642-4646.

[11] B. Han, R. Lang, B. Qiao, A. Wang, T. Zhang, Chin. J. Catal., 2017, 38, 1498-1507.

[12] X. F. Yang, A. Q. Wang, B. T. Qiao, J. Li, J. Y. Liu, T. Zhang, Acc. Chem. Res., 2013, 46, 1740-1748.

[13] X. J. Cui, W. Li, P. Ryabchuk, K. Junge, M. Beller, Nat. Catal., 2018, 1, 385-397.

[14] F. Chen, X. Jiang, L. Zhang, R. Lang, B. Qiao, Chin. J. Catal., 2018, 39, 893-898.

[15] T. Li, F. Liu, Y. Tang, L. Li, S. Miao, Y. Su, J. Zhang, J. Huang, H. Sun, M. Haruta, A. Wang, B. Qiao, J. Li, T. Zhang, Angew. Chem. Int. Ed., 2018, 57, 7795-7799.

[16] S. E. J. Hackett, R. M. Brydson, M. H. Gass, I. Harvey, A. D. Newman, K. Wilson, A. F. Lee, Angew. Chem. Int. Ed., 2007, 46, 8593-8596.

[17] T. Ishida, T. Honma, K. Nakada, H. Murayama, T. Mamba, K. Kume, Y. Izawa, M. Utsunomiya, M. Tokunaga, J. Catal., 2019, 374, 320-327.

[18] T. T. Chao, X. Luo, W. X. Chen, B. Jiang, J. J. Ge, Y. Lin, G. Wu, X. Q. Wang, Y. M. Hu, Z. B. Zhuang, Y. E. Wu, X. Hong, Y. D. Li, Angew. Chem. Int. Ed., 2017, 56, 16047-16051.

[19] D. I. Enache, J. K. Edwards, P. Landon, B. Solsona-Espriu, A. F. Carley, A. A. Herzing, M. Watanabe, C. J. Kiely, D. W. Knight, G. J. Hutchings, Science, 2006, 311, 362-365.

[20] J. F. Moulder, J. Chastain, Handbook of X-ray Photoelectron Spectroscopy: A Reference Book of Standard Spectra for Identification, Interpretation of XPS Data, Physical Electronics Division, Perkin-Elmer Corporation, 1992.

[21] D. S. Mannel, J. King, Y. Preger, M. S. Ahmed, T. W. Root, S. S. Stahl, ACS Catal., 2018, 8, 1038-1047.

[22] P. Mäki Arvela, A. V. Tokarev, E. V. Murzina, B. Campo, T. Heikkilä, J. M. Brozinski, D. Wolf, D. Y. Murzin, Phys. Chem. Chem. Phys., 2011, 13, 9268-9280.

\section{Graphical Abstract}

Chin. J. Catal., 2020, 41: 1812-1817 doi: 10.1016/S1872-2067(20)63651-8

\section{A palladium single-atom catalyst toward efficient activation of molecular oxygen for cinnamyl alcohol oxidation}

Qinghao Shang, Nanfang Tang *, Haifeng Qi, Shuai Chen, Guoliang $\mathrm{Xu}$, Chuntian Wu, Xiaoli Pan, Xiaodong Wang, Yu Cong *

Dalian Institute of Chemical Physics, Chinese Academy of Sciences; University of Chinese Academy of Sciences

Allylic alcohols were adsorbed on Pd atoms and produced partially dehydrogenated intermediates, whereas active oxygen species behaving chemically like singlet- $\mathrm{O}_{2}$ were generated on the interaction of $\mathrm{O}_{2}$ with $\mathrm{Pd}_{1} / \mathrm{Al}_{2} \mathrm{O}_{3}$. Then the two active species reacted and formed the desired alkenyl aldehyde.

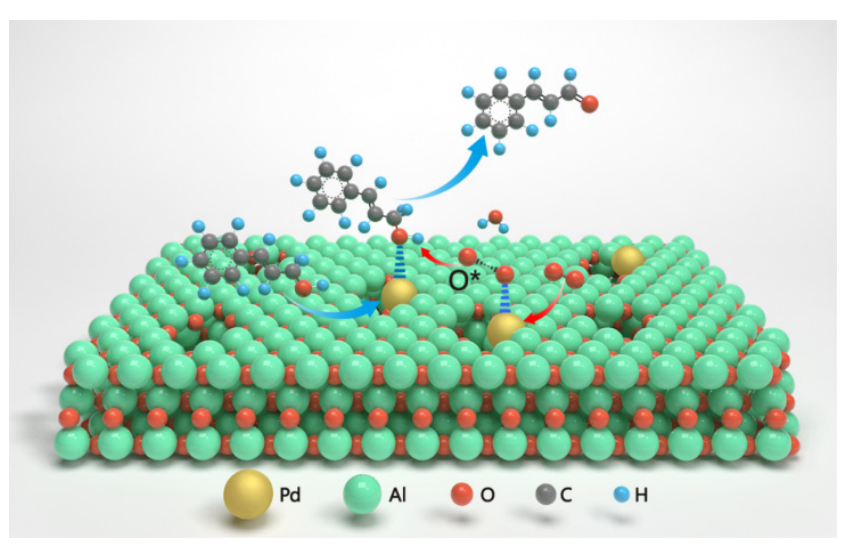


[23] K. Murata, Y. Mahara, J. Ohyama, Y. Yamamoto, S. Arai, A. Satsuma, Angew. Chem., Int. Ed., 2017, 56, 15993-15997.

[24] L. Ding, H. Yi, W. Zhang, R. You, T. Cao, J. Yang, J. Lu, W. Huang, ACS Catal., 2016, 6, 3700-3707.

[25] M. Peter, J. M. Flores Camacho, S. Adamovski, L. K. Ono, K. H. Dostert, C. P. O'Brien, B. Roldan Cuenya, S. Schauermann, H. J. Freund, Angew. Chem., Int. Ed., 2013, 52, 5175-5179.

[26] P. Liu, Y. Zhao, R. Qin, S. Mo, G. Chen, L. Gu, D. M. Chevrier, P. Zhang, Q. Guo, D. Zang, B. Wu, G. Fu, N. Zheng, Science, 2016, 352, 797-801.

[27] V. V. Kaichev, I. P. Prosvirin, V. I. Bukhtiyarov, H. Unterhalt, G. Rupprechter, H. J. Freund, J. Phys. Chem. B, 2003, 107, 3522-3527.

[28] J. D. Grunwaldt, M. Caravati, M. Ramin, A. Baiker, Catal. Lett., 2003, 90, 221-229.

[29] T. Mallat, A. Baiker, Chem. Rev., 2004, 104, 3037-3058.

[30] H. L. Tang, F. Liu, J. K. Wei, B. T. Qiao, K. F. Zhao, Y. Su, C. Z. Jin, L. Li,
J. Y. Liu, J. H. Wang, T. Zhang, Angew. Chem. Int. Ed., 2016, 55, 10606-10611.

[31] V. Ramalingam, P. Varadhan, H. C. Fu, H. Kim, D. L. Zhang, S. M. Chen, L. Song, D. Ma, Y. Wang, H. N. Alshareef, J. H. He, Adv. Mater., 2019, 31, 1903841.

[32] J. J. Li, Q. Q. Guan, H. Wu, W. Liu, Y. Lin, Z. H. Sun, X. X. Ye, X. S. Zheng, H. B. Pan, J. F. Zhu, S. Chen, W. H. Zhang, S. Q. Wei, J. L. Lu, J. Am. Chem. Soc., 2019, 141, 14515-14519.

[33] N. Tang, Y. Cong, Q. Shang, C. Wu, G. Xu, X. Wang, ACS Catal., 2017, 7, 5987-5991.

[34] N. Tang, Y. Zhang, F. Lin, H. Lu, Z. Jiang, C. Li, Chem. Commun., 2012, 48, 11647-11649.

[35] R. Long, K. Mao, M. Gong, S. Zhou, J. Hu, M. Zhi, Y. You, S. Bai, J. Jiang, Q. Zhang, X. Wu, Y. Xiong, Angew. Chem. Int. Ed., 2014, 53, 3205-3209.

[36] N. Tang, Z. Jiang, C. Li, Green Chem., 2015, 17, 817-820.

\title{
单原子Pd催化剂活化分子氧用于肉桂醇氧化
}

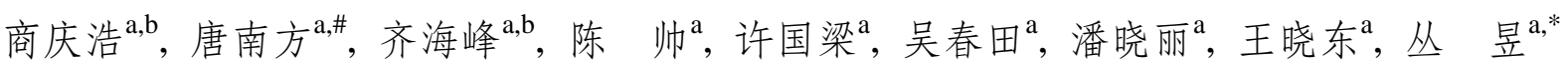 \\ a中国科学院大连化学物理研究所中国科学院航天催化材料重点实验室, 辽宁大连 116023 \\ ${ }^{\mathrm{b}}$ 中国科学院大学, 北京100049
}

摘要: 在温和条件下借助分子氧实现有机分子(包括醇类、糖类、碳烃化合物、CO等)的选择性氧化是现代化学中重要的 研究课题. 其中, 在温和条件下高效的活化氧气一直被视为分子氧氧化反应的关键步骤和巨大挑战. 一般而言, 得益于适 宜的配位结构、均一的活性金属中心和配体, 有机金属催化剂在醇氧化反应中一直有着广泛的应用, 但同时存在着难以分 离和回收的问题. 而与均相催化剂一样有着高原子利用率的单原子催化剂自其概念报道以来, 在催化领域吸引了越来越 多的注意力. 愈来愈多的研究者也开始涉足研究单原子催化剂在分子氧氧化反应中的应用. 尽管已经取得一些不错的结 果, 但分子氧的活化机制以及催化反应路径仍然有很多疑问有待揭示.

本文在富含不饱和五配位铝的氧化铝载体上分别负载了单原子分散和纳米颗粒的 $\mathrm{Pd}$, 制备了相同负载量的 $\mathrm{Pd} / \mathrm{Al}_{2} \mathrm{O}_{3}$ 催化剂. 其中单原子 $\mathrm{Pd}_{1} / \mathrm{Al}_{2} \mathrm{O}_{3}$ 催化剂表现出非常好的肉桂醇氧化活性, 在 $80{ }^{\circ} \mathrm{C}$ 反应 $8 \mathrm{~h}$ 能达到 $92 \%$ 肉桂醇转化率, 其TOF值 是纳米颗粒 $\mathrm{Pd} / \mathrm{Al}_{2} \mathrm{O}_{3}$ 催化剂的 15.5 倍, 与类似反应条件下的其他文献报道的数值相当. 我们还通过一系列表征提出了反应 过程中具体的 $\mathrm{O}_{2}$ 的活化机理和进一步的整体反应路径.

XPS, XANES, CO-DRIFT等结果表明, $\mathrm{Pd} / \mathrm{Al}_{2} \mathrm{O}_{3}$ 和 $\mathrm{Pd}_{1} / \mathrm{Al}_{2} \mathrm{O}_{3}$ 催化剂中Pd的价态迥然不同, 结合二者催化活性的显著差 异, 我们推断部分还原的 $\mathrm{Pd}^{\delta+}$ 正价态物种才是 $\mathrm{Pd}_{1} / \mathrm{Al}_{2} \mathrm{O}_{3}$ 催化剂中真正的活性中心. 进一步结合 ${ }^{27} \mathrm{Al} N M R$ 的表征结果发现, $\mathrm{Pd}_{1} / \mathrm{Al}_{2} \mathrm{O}_{3}$ 催化剂中的 $\mathrm{Pd}$ 与富含不饱和五配位铝 $\left(\mathrm{Al}^{3+}{ }_{\text {penta }}\right)$ 的 $\mathrm{Al}_{2} \mathrm{O}_{3}$ 之间形成强相互作用, 从而导致其以单原子形式分散并具 有独特的电子性质. 为了揭示本工作中所涉及的具体的活化过程和反应机理, 我们进行了原位紫外光谱和电子顺磁共振 光谱表征, 发现肉桂醇分子吸附到单原子Pd上后, 生成了部分脱氢的中间产物, 同时分子氧在单原子Pd上活化, 形成了单线 态氧活性物种 $\left({ }^{1} \mathrm{O}_{2}\right)$.

综合以上结果, 我们推导出一个在 $\mathrm{Pd}_{1} / \mathrm{Al}_{2} \mathrm{O}_{3}$ 上进行的活化分子氧进行肉桂醇选择性氧化的分步反应路径. 首先, 肉桂 醇分子吸附到单原子 Pd上, 发生电荷转移生成部分脱氢的中间产物, 同时, 分子氧也在 $\mathrm{Pd}$ 上活化, 生成单线态氧物种 ${ }^{1} \mathrm{O}_{2}$, 然 后和肉桂醇中间产物反应, 生成目标产物肉桂醛.

关键词: 单原子催化; 钯; 醇氧化; 氧气活化; 金属载体相互作用

收稿日期: 2020-02-27. 接受日期: 2020-03-31. 出版日期: 2020-12-05.

*通讯联系人. 电话: (0411)84379676; 传真: (0411)84685940; 电子信箱: ycong@dicp.ac.cn

\#通讯联系人. 电子信箱: nftang@dicp.ac.cn

基金来源：国家自然科学基金(21802134); 国家科技重大专项(2017-III-0005-0030).

本文的电子版全文由Elsevier出版社在ScienceDirect上出版(http://www.sciencedirect.com/science/journal/18722067). 